\title{
PROSPEK PENERAPAN PP NO. 35 TAHUN 2007 SEBAGAI PENGATURAN INSENTIF PERPAJAKAN UNTUK MENDORONG PENINGKATAN R\&D
}

\author{
Brian A. Prastyo ${ }^{1}$ \\ Abstrak
}

This article elaborates on tax incentive for research and development area. In recent government policy of the Republic Indonesia has governed under the Government Regulation number 35 year 2007. The author deems that that regulation has some fundamentals weakness. The policy toward tax incentive commonly should make corporation can save in huge amount. That aspect is also contained disadvantage to be abused. Hence abuse through duty free privilege could happen like on imported goods selling which is imported by that privilege abuse in domestic market. Under the author sights then government ought to launch any exclusive policy for certain company that has significant program to conducting research and development. Then the author advises to protect that policy also must be secured by worthy system of incentive's application will be approved to the right one only.

Kata kunci: hukum bisnis, perpajakan, kepabeanan, penyalahgunaan

I. Pengaturan Insentif Perpajakan Menurut PP No. 35 Tahun 2007

\section{A. Latar Belakang dan Tujuan Pengaturan}

Peraturan Pemerintah Nomor 35 Tahun 2007 tentang Pengalokasian Sebagian Pendapatan Badan Usaha Untuk Peningkatan Kemampuan Perekayasaan, Inovasi, dan Difusi Teknologi (untuk selanjutnya disebut PP Alokasi Pendapatan Badan Usaha) ditetapkan, diundangkan, dan mulai berlaku sejak tanggal 22 Juni 2007. Kurang lebih 2 (dua) tahun sebelumnya, tepatnya pada tanggal 30 Juni 2005, Menteri Negara Riset dan Teknologi Kusmayanto Kadiman dalam sebuah acara lomba desain di Jakarta mengungkapkan hal-hal yang dapat dianggap sebagai indikasi mengenai motivasi atau alasan dari adanya peraturan tersebut. Ia menyatakan bahwa PP tersebut untuk

1 Penulis adalah Staf Pengajar Fakultas Hukum Universitas Indonesia, alamat korespondensi: brian.amy@ui.ac.id. 
mendorong kegiatan riset dan pengembangan di Indonesia. Menurutnya kalangan industri dalam negeri maupun swasta enggan melakukan riset di Indonesia, karena tidak ada keuntungan langsung yang dinikmati mereka setelah melakukan kegiatan riset di Indonesia. Padahal, dana yang dikeluarkan untuk kegiatan riset tak sedikit. Kemudian ia juga mengatakan bahwa negara-negara tetangga telah memberikan insentif pajak itu sejak beberapa tahun lalu. Akibatnya, tidak seperti Indonesia, mereka tidak lagi menjadi lokasi perakitan. Namun, menjadi tempat riset dan menyumbangkan berbagai inovasi. ${ }^{2}$

Berdasarkan pada pernyataan tersebut dapat ditafsirkan bahwa Menristek sangat meyakini bahwa insentif pajak untuk kegiatan riset dan pengembangan dapat mendatangkan investasi baru atau setidaknya meningkatkan kualitas investasi yang sudah ada di Indonesia. Pandangan yang mengkaitkan antara insentif perpajakan dengan kualitas investasi sesungguhnya bukan suatu hal yang baru, tetapi secara substansial telah menjadi pokok perhatian yang mendalam bagi banyak pemerintahan di seluruh dunia. Bahkan Persatuan BangsaBangsa melalui salah satu instrumennya, yaitu United Nations Conference on Trade and Development pada tahun 2000 merilis suatu survey global yang bertajuk Tax Incentives and Foreign Direct Investment.

Dalam survey tersebut insentif perpajakan didefinisikan sebagai insentif apapun yang mengurangi beban pajak dari suatu perusahaan yang bertujuan untuk mendorong perusahaan tersebut untuk berinvestasi di suatu proyek atau sektor tertentu, meliputi namun tidak terbatas pada pengurangan tarif pajak untuk laba, tax holiday, pengurangan tariff untuk importasi peralatan, komponen, dan bahan baku. ${ }^{3}$ Survey tersebut juga mencatat karakteristik insentif perpajakan yang sangat penting yaitu bahwa insentif perpajakan hampir selalu diberikan dengan kondisi atau syarat tertentu yang tidak terpisahkan. Dalam survey ini dicontohkan China yang memberikan pengembalian pajak sampai sebesar $40 \%$ dari laba yang dihasilkan oleh suatu perusahaan yang dimiliki pihak asing, tetapi uang tersebut wajib diinvestasikan kembali atau direinvestasikan untuk meningkatkan modal dari perusahaan atau mendirikan perusahaan baru. Laba tersebut

${ }^{2}$ Zat/OL-02, Industri Lakukan Riset, Dapat Potongan Pajak, Media Indonesia, 30 Juni 2005 .

${ }^{3}$ ASIT Advisory Studies No. 16, Tax Incentives and Foreign Direct Investment: A Global Survey, (United Nations Conference on Trade and Development, 2000), hal. 12. 
harus direinvestasikan dalam waktu sekurang-kurangnya 5 (lima) tahun. Jika sebelum jangka waktu itu berakhir, uang tersebut ditarik, maka perusahaan tersebut harus membayar pajak. ${ }^{4}$

Kembali ke pandangan Menristek tersebut di awal dapat dikatakan bahwa insentif perpajakan sebagai pilihan kebijakan untuk mendorong berkembangnya industri dan investasi yang berbasis riset dan pengembangan adalah suatu pilihan yang strategis. Namun demikian, untuk dapat mewujudkan gagasan tersebut menjadi suatu kesuksesan diperlukan pula tindakan antisipasi terhadap berbagai permasalahan dan kelemahan yang lahir dari metode ini yang dapat diketahui dari pengalaman berbagai negara di dunia yang telah pernah menggunakannya.

\section{B. Inti Pengaturan}

PP Alokasi Pendapatan Badan Usaha pada intinya mengatur 3 (tiga) hal, yaitu tindakan pengalokasian sebagian pendapatan badan usaha, ruang lingkup kegiatan yang termasuk peningkatan kemampuan perekayasaan, inovasi, dan difusi teknologi, dan insentif. Tindakan pengalokasian sebagian pendapatan badan usaha harus ditujukan untuk meningkatkan kemampuan perekayasaan, inovasi, dan difusi teknologi dalam meningkatkan kinerja produksi dan/atau daya saing barang dan/atau jasa yang dihasilkan. Sedangkan ruang lingkup dari kegiatan peningkatan kemampuan perekayasaan, inovasi, dan difusi teknologi itu sendiri adalah: (a) penelitian, pengembangan, dan/atau penerapan teknologi; dan/atau, (b) pemanfaatan hasil penelitian dan pengembangan perguruan tinggi dan/atau lembaga penelitian dan pengembangan. Untuk melaksakan kegiatan tersebut suatu badan usaha dapat bekerjasama dengan perguruan tinggi, lembaga penelitian dan pengembangan, dan badan usaha lain, melalui bentuk-bentuk seperti lisensi, kerjasama, dan pelayanan jasa ilmu pengetahuan dan teknologi.

Insentif yang berupa insentif perpajakan, kepabeanan, dan/atau bantuan teknis penelitian dan pengembangan akan diberikan bagi badan usaha yang melakukan alokasi sebagian pendapatannya. Besar dan jenis insentif perpajakan dan kepabeanan dapat diberikan sepanjang diatur dalam ketentuan Peraturan Perundang-undangan di bidang perpajakan dan kepabeanan. Sedangkan, bantuan teknis penelitian dan pengembangan dapat berupa penempatan tenaga ahli 
dan/atau pemanfaatan fasilitas laboratorium di lembaga penelitian dan pengembangan pemerintah, kecuali terhadap: (a) kegiatan yang dilakukan di luar negeri; (b) kegiatan pengawasan dan/atau pengujian rutin terhadap kualitas produk, bahan, peralatan, produk dan/atau proses; (c) pengumpulan data; (d) survei efisiensi atau studi manajemen; (e) riset pasar dan/atau promosi penjualan; dan (f) pembelian dan/atau pembayaran royalti teknologi dari entitas lain di luar negeri.

\section{Prosedur Pemberian Insentif}

Badan Usaha mengajukan permohonan untuk mendapatkan rekomendasi insentif secara tertulis kepada Menteri, dilengkapi dengan proposal kegiatan dan bentuk insentif. Menteri membentuk Tim Pengkajian dan Penilaian, guna melakukan pengkajian dan penilaian terhadap permohonan insentif. Hasil pengkajian dan penilaian disampaikan kepada Menteri dalam bentuk saran dan pertimbangan. Pengkajian dan penilaian dilaksanakan paling lama 30 (tiga puluh) hari kerja sejak permohonan insentif diterima secara lengkap. Menteri dapat memberikan atau tidak memberikan rekomendasi insentif dengan memperhatikan saran dan pertimbangan Tim Pengkajian dan Penilaian. Menteri menyampaikan pemberitahuan persetujuan atau penolakan pemberian rekomendasi insentif sebagaimana dimaksud pada ayat (1) paling lambat 14 (empat belas) hari kerja sejak penerimaan saran dan pertimbangan Tim Pengkajian dan Penilaian. Dalam hal Menteri memberikan rekomendasi insentif, rekomendasi disampaikan kepada Badan Usaha dengan tembusan kepada instansi pemerintah yang berwenang dalam pemberian insentif. Badan Usaha mengajukan permohonan insentif kepada instansi pemerintah yang berwenang disertai dengan rekomendasi insentif. Tata cara pengajuan permohonan insentif perpajakan dan kepabeanan dilakukan sesuai dengan ketentuan Peraturan Perundang-undangan di bidang perpajakan dan kepabeanan.

\section{Kewajiban untuk Badan Usaha yang Memperoleh Insentif}

Pada setiap akhir tahun dan akhir kegiatan, Badan Usaha yang mendapat insentif wajib menyerahkan laporan kegiatan peningkatan kemampuan, perekayasaan, inovasi, dan difusi teknologi kepada Menteri. Laporan tersebut paling sedikit memuat pencapaian kegiatan yang telah dilakukan dan sejauh mana terpenuhinya kriteria yang ditentukan yang meliputi: (a) kegiatan peningkatan kemampuan 
perekayasaan, inovasi, dan difusi teknologi, (b) potensi peningkatan kinerja produksi dan/atau daya saing barang dan/atau jasa; (c) pemanfaatan hasil penelitian dan pengembangan di dalam negeri; dan (d) penggunaan sumber daya dalam negeri. Menteri dapat melakukan verifikasi laporan guna memberikan saran dan pertimbangan penghentian atau perpanjangan insentif kepada instansi pemerintah yang berwenang. Verifikasi dilakukan dengan menjaga kerahasiaan informasi yang diperoleh.

\section{Tinjauan Umum Mengenai Insentif Perpajakan Untuk Kegiatan R\&D}

Insentif perpajakan untuk kegiatan riset dan pengembangan (untuk selanjutnya disebut Insentif R\&D) telah diberlakukan di berbagai negara di dunia. Insentif $R \& D$ ini umumnya dibuat untuk mendorong badan usaha untuk melakukan kegiatan riset dan pengembangan teknologi. Jenis insentif yang diberikan biasanya berupa pengurangan (reductions) dari jumlah pajak yang harus dibayar (bahkan dalam kondisi ketika badan usaha tersebut mengalami kerugian pemerintah dapat memberikannya uang sebagai kompensasi atas biaya riset dan pengembangan yang telah dilakukan yang telah diperhitungkan dalam kewajiban pajak), atau menetapkannya sebagai penghasilan tidak kena pajak (exemption). ${ }^{5}$

Menurut Debbie McAlpine, praktisi dari PricewaterhouseCooper, insentif r\&d memiliki dua efek bagi badan usaha. Pertama, insentif tersebut mendorong dilakukannya investasi dalam proyek-proyek yang belum jelas keuntungannya, sehingga dalam kondisi normal sulit memperoleh pendanaan. Kedua, insentif tersebut menghargai pengembangan hak kekayaan intelektual dari perusahaan tersebut. ${ }^{6}$ Lebih lanjut ia mengungkapkan bahwa skema-skema insentif $r \& d$ dapat berbasis volume, incremental, atau keduanya. Skema insentif berbasiskan volume misalnya pengurangan pajak dengan mengacu pada total jumlah pengeluaran $r \& d$ yang diperbolehkan. Sedangkan skema insentif inkremental adalah skema yang berbasiskan additional increment of $R \& D$ selama beberapa tahun.?

${ }^{5}$ Belinda L Heath, The Importance of Research and Development Tax Incentives in the World Market, Michigan State University-DCL Journal of International Law, Fall 2002, hal. 351 .

6 Debbie McAlpine, "Tax Credits for R\&D Investment", (London: PricewaterhouseCooper, 2005), hal. 2. 
Di Eropa insentif R\&D dipandang sebagai kebijakan yang memiliki peran yang penting dalam meningkatkan pengeluaran $R \& D$ sektor swasta. Namun mengingat tidak adanya keseragaman pengaturan mengenai insentif r\&d di setiap negara, maka kriteria insentif r\&d yang dianggap baik adalah jika: (a) biaya administrasinya rendah, (b) mengurangi kewajiban pajak dari badan usaha yang menguntungkan dalam proporsi sesuai dengan pengeluaran badan usaha tersebut untuk riset dan pengembangan, (c) menawarkan "pajak negatif", misalnya cash premium untuk perusahaan baru yang prospeknya baik, (d) menyediakan bonus ekstra jika pengeluaran r\&d badan usaha telah mencapai jumlah yang tinggi dan tingkat pertumbuhannya stabil, (e) menyediakan insentif untuk kegiatan $\mathrm{r} \& d$ yang dikerjakan pihak ketiga tetapi dibiayai oleh badan usaha, (f) metode evaluasi yang sesuai untuk menilai efektifitas dari insentif $r \& d$ terutama dalam kaitannya dengan pendeknya waktu ke pasar, jumlah total dari pengeluaran r\&d, peningkatan dalam jumlah personil $r \& d$, perbaikan dalam infrastruktur $r \& d$, perbaikan dalam kerjasama industri-akademisi, dan perilaku lain yang membuat kegiatan r\&d berjalan lebih sistematik dan inovasi berlangsung dalam tingkatan yang lebih tinggi. ${ }^{8}$ Sedangkan kebijakan insentif $r \& d$ dianggap memiliki dampak negatif jika: (a) menerapkan caps on the eligibility for tax incentives for $R \& D$, (b) memuat definisi yang tidak pasti mengenai kegiatan dan pengeluaran untuk r\&d. ${ }^{9}$

Satu hal yang sangat menarik ialah bahwa ternyata skema insentif R\&D di Amerika Serikat justru di mata para akademisinya tidak dianggap sebagai skema yang sudah baik. Belinda $L$ Heath dalam artikelnya yang dimuat di Journal of International Law - Michigan State University bahkan menyatakan bahwa insentif r\&d di Amerika Serikat tidak efektif, kekurangan ekuitas vertikal dan horisontal, dan melahirkan biaya administrasi yang tinggi, sehingga tidak layak dijadikan acuan bagi negara-negara lain. ${ }^{10}$

\section{${ }^{7}$ Ibid.}

${ }^{8}$ Eurochambers, Position Paper 2006: Position on R\&D Tax Incentives, Juli 2006, hal. $2-3$.

\section{${ }^{9}$ Ibid.}

${ }^{10}$ Heath, Op.Cit., hal. 368 . Untuk tinjauan lain terhadap kebijakan insentif r\&d di Amerika Serikat dapat merujuk pada Tassey, Gregory, Tax Incentives for Innovation: Time to Restructure the R\&D Tax Credit, 1 Agustus 2007, Moris, Fransisco, The US Research and Experimentation Tax Credit in the 1990s, National Science Foundation 05-316, Juli 2005, atau Dumagan, Jesus C, Re-examining the Cost Effectiveness of the Research and Experimentation Tax Credit, Juni 1995. 


\section{Aspek yang Perlu Dipertimbangkan Dalam Mengatur Insentif R\&D}

Pemberian insentif perpajakan berdampak pada berkurangnya penerimaan negara. Namun apabila kebijakan ini berhasil meningkatkan investasi, maka kebijakan ini dapat dikatakan berhasil mencapai tujuannya. Oleh karena itu, setiap pengaturan insentif perpajakan haruslah dibuat sedemikian rupa, sehingga secara efektif mampu mewujudkan tujuannya dengan meminimalisir kehilangan penerimaan pajak yang potensial. ${ }^{11}$

Dalam sebuah hasil riset yang dirilis oleh UNCTAD disebutkan beberapa elemen kunci untuk merancang sebuah kebijakan insentif perpajakan yang baik. Pertama, target penerima dan tujuan pemberian insentif tersebut harus jelas, sebab jika tidak, dapat berdampak pada hilangnya penerimaan pajak yang potensial dan tujuan pemberian insentif menjadi tidak tercapai. Dalam laporan tersebut disebutkan salah satu contohnya adalah pemberian insentif perpajakan di Lebanon. Diceritakan bahwa pemerintah Lebanon ingin mendorong investor untuk merehabilitasi gedung-gedung yang rusak karena perang dan membangun gedung-gedung baru untuk kebutuhan masyarakat. Untuk mewujudkan tujuan tersebut, dikeluarkanlah kebijakan insentif perpajakan. Tetapi insentif itu hanya dirancang untuk mendorong pendirian gedung baru. Akibatnya tidak ada investor yang berminat merenovasi gedung-gedung lama yang rusak, sehingga gedung-gedung lama tersebut tetap terbengkalai dan tidak dapat dimanfaatkan. Selain itu, akibat lainnya ialah terjadinya kelebihan pasokan atau oversupply dari gedung-gedung baru, padahal kemampuan likuiditas masyarakat belum sanggup untuk menyerap semuanya.

Elemen kunci kedua adalah pengadministrasian insentif perpajakan. Walaupun diatur dalam peraturan perpajakan, seringkali administrasi insentif tersebut dilakukan oleh instansi pemerintah selain kantor pajak. Sesungguhnya, banyaknya instansi pemerintah yang menangani insentif perpajakan cenderung menumbuhkan rasa ketidaknyamanan dalam melakukan bisnis, karena investor umumnya menghendaki birokrasi yang sederhana, misalnya berurusan dengan satu instansi pemerintah saja.

Elemen kunci ketiga adalah sistem insentif haruslah mudah dipahami. Misalnya, lebih baik menuliskan secara jelas nama-nama provinsi atau daerah yang menjadi lingkup keberlakuan insentif, daripada mengklasifikasikannya sebagai "daerah tertinggal". Atau lebih baik menyebutkan secara spesifik sektor atau industri yang berhak menerima insentif misalnya industri sepatu, garmen, atau kerajinan tangan, daripada

"UNCTAD, hal. 23. 
mengaturnya secara umum sebagai "industri padat karya". Penyebutan secara spesifik tersebut meminimalisir perbedaan penafsiran yang tidak produktif.

Elemen kunci keempat adalah bahwa insentif perpajakan harus dikoordinasikan dengan baik. Pemerintah daerah atau di negara-negara federal pemerintah negara bagian seringkali menggunakan kewenangannya dalam membuat kebijakan yang tergolong sebagai insentif perpajakan untuk menarik investor. Persoalannya nilai insentif tersebut terkadang tidak dihitung secara cermat dan tidak dikoordinasikan dengan baik dengan insentif yang diberikan oleh pemerintah pusat. Akibatnya, total insentif yang dapat diterima oleh badan usaha (yang notabene dari sisi pemerintah dipandang sebagai pengeluaran) hampir sama besarnya dengan nilai investasi yang ditanamkan. Contohnya adalah insentif perpajakan untuk pendirian pabrik Mercedes Benz di Tuscaloosa, Alabama, Amerika Serikat. Nilai investasi dari pabrik itu adalah sebesar $\$ 300$ Juta, tetapi insentif perpajakan yang diberikan oleh negara bagian Alabama yang meliputi insentif untuk pembangunan pabrik, infrastruktur, dan pelatihan tenaga kerja seteleh dikalkulasi jumlah mencapai $\$ 250$ Juta.

Easson \& Zolt mengingatkan 3 (tiga) isu penting yang terkait dengan penentuan badan usaha yang berhak menerima insentif. Pertama, apakah insentif tersebut akan diberikan secara otomatis atau ditentukan oleh pejabat yang berwenang (discrietionary entitlement). Penentuan pihak yang berhak memperoleh insentif oleh pejabat yang berwenang dapat memiliki efek positif dan negatif. Positifnya ialah sistem ini dapat memastikan insentif hanya diberikan jika badan usaha yang bersangkutan mengalami peningkatan pengeluaran $R \& D$ di tahun tersebut dibandingkan dengan tahun-tahun sebelumnya. Negatifnya, sistem ini melahirkan beban pengadministrasian yang lebih besar, cara pengelolaan yang kurang transparan, dan dapat membuka peluang kolusi dan korupsi. Namun, menurut mereka sistem pemberian insentif yang memilih memberlakukan salah satu dari dua metode tersebut secara murni sesungguhnya tidaklah umum. Justru metode yang umum adalah gabungan dari keduanya. Misalnya, dalam sistem pemberian insentif yang otomatis, prosedurnya dapat diawali dengan pemberian sertifikasi dari pejabat tertentu yang menyatakan bahwa badan usaha tersebut dapat memenuhi persyaratan untuk memperoleh insentif.

Isu kedua adalah kondisi-kondisi yang dipersyaratkan terhadap calon penerima insentif. Dalam hal ini calon penerima insentif dapat diwajibkan untuk menunjukkan hal-hal tertentu untuk memastikan bahwa mereka memenuhi persyaratan yang ditetapkan. Hal-hal yang dimaksud tersebut dapat meliputi: (a) adanya persetujuan atau sertifikasi dari pejabat yang berwenang, (b) menunjukkan kondisi faktual yang memuaskan, (c) 
memperoleh penilaian atas aset-aset tertentu, dan (d) memenuhi persyaratan lanjutan tertentu.

Isu ketiga adalah penentuan telah terpenuhinya persyaratan oleh calon penerima insentif (determination of eligibility). Pembuatan kebijakan insentif perpajakan biasanya melibatkan lebih dari satu instansi pemerintah. Untuk itu perlu ada pembagian kewenangan yang jelas antara masing-masing instansi, karena tujuan pekerjaan dari masing-masing instansi biasanya tidak sama. Dalam hal ini departemen keuangan biasanya menjadi pihak yang berperan dalam menyusun kebijakan perpajakannya, misalnya persentase potongan dari pajak penghasilan yang dapat diberikan. Sedangkan, instansi yang lain membuat kriteria badan usaha yang berhak menerima insentif tersebut. Kejelasan pengaturan terhadap kewenangan masing-masing instansi dapat mencegah terjadi overlapping kewenangan pada masing-masing instansi.

Setelah tahap perancangan dilewati, tahap yang sangat penting dari suatu kebijakan insentif perpajakan adalah tahap pelaksanaan. Dalam tahap ini ada beberapa hal yang perlu diperhatikan, yaitu tanggal mulai berlakunya kebijakan (commencement), jangka waktu dan berakhirnya kebijakan (duration and termination), dan kaitannya dengan aturan-aturan mengenai depresiasi dan kerugian (relationship to depreciation and loss rules). Selain itu, isu-isu lain yang juga berkaitan diantaranya adalah isu mengenai kepatuhan (compliance) dan penyalahgunaan (abuse).

Untuk memastikan bahwa penerima insentif adalah badan usaha yang benar-benar memenuhi persyaratan yang ditentukan, maka suatu sistem pemantauan kepatuhan yang formal harus dibuat. Formalitas tersebut akan memaksa badan usaha yang bersangkutan untuk secara sungguh-sungguh memberikan informasi yang memang diperlukan untuk menilai terpenuhi tidaknya persyaratan tersebut. Oleh karena itu, formalitas tersebut haruslah dibuat sedemikian rupa, sehingga pejabat yang berwenang dapat menilai apakah badan usaha yang bersangkutan layak untuk mendapat insentif atau tidak.

Kebijakan insentif perpajakan dapat membuat badan usaha menghemat sejumlah besar uang, sehingga kebijakan ini terkadang disalahgunakan. Beberapa bentuk penyalahgunaan insentif perpajakan adalah round-tripping, double dipping, transfer pricing, over valuation, abuse of duty free privileges, asset stripping and "fly-by-night" operations, dan korupsi.

Round-tripping biasanya terjadi terhadap insentif perpajakan yang dibatasi untuk investasi asing atau terhadap investasi yang mensyaratkan kepemilikan minimum untuk asing. Salah satu caranya ialah dengan mengirimkan uang ke luar negeri, kemudian dengan menunjuk orang-orang asing sebagai pemegang saham uang tersebut digunakan untuk mendirikan 
satu perusahaan di dalam negeri, sehingga seolah-olah sebagai penanaman modal asing.

Double dipping biasanya terjadi terhadap insentif perpajakan yang dibatasi untuk investor baru. Caranya, perusahaan yang sudah ada mendirikan perusahaan baru untuk memperoleh insentif tersebut. Cara yang lain adalah, perusahaan yang sudah menikmati insentif pajak, misalnya tax holiday, menjual perusahaan tersebut menjelang berakhirnya masa tax holiday, lalu mendirikan perusahaan baru lagi untuk memperoleh insentif tax holiday lagi.

Transfer pricing biasanya terjadi pada saat (a) satu investor melakukan dua atau lebih kegiatan, yang mana satu kegiatan tersebut berhak memperoleh insentif dan yang lainnya tidak, (b) satu investor beroperasi di dua atau lebih lokasi, dimana di satu lokasi ia berhak memperoleh insentif dan di lokasi lainnya tidak, (c) satu investor memiliki dua atau lebih anak perusahaan, yang mana satu anak perusahaan menikmati insentif perpajakan dan yang lainnnya tidak. Dalam kondisi seperti ini, si investor biasanya akan mengalokasikan profit sebanyak-banyaknya ke perusahaannya atau kegiatannya yang berhak memperoleh insentif.

Over valuation dapat terjadi dalam bentuk penggelembungan nilai aset. Misalnya, untuk memenuhi persyaratan nilai aset tertentu agar sebuah badan usaha dapat memperoleh insentif, asetnya dinaikkan nilainya.

Penyalahgunaan insentif bebas bea masuk (abuse duty free privileges) dapat terjadi misalnya dalam bentuk penjualan barang impor yang dibeli dengan memanfaatkan insentif tersebut di pasar dalam negeri. Oleh karena itu, salah satu solusi untuk mengatasinya adalah membatasi insentif hanya untuk barang berupa mesin misalnya, yang sulit untuk dijual kembali.

Asset stripping and "fly-by-night" operations biasanya terjadi saat suatu negara menerapkan kebijakan tax holiday dan export processing zones. Cara kerja pelaku "fly by night" adalah dengan membuat suatu perusahaan atau kegiatan untuk dapat menikmati insentif perpajakan yang diberikan dan setelah masa berlakunya insentif akan habis ia akan meninggalkan perusahaan atau kegiatan tersebut dan memulai lagi operasinya di negara lain yang menawarkan kebijakan insentif yang serupa. Sedangkan pelaku asset stripping biasanya perusahaan asing yang mengakuisisi perusahaan dalam negeri dengan harga yang sangat murah, kemudian bukannya mengembangkan perusahaan tersebut, perusahaan asing ini malah menghabisi aset-aset dari perusahaan dalam negeri tersebut, misalnya dengan menjual habis aset-aset yang ada.

Khusus mengenai pemberian insentif perpajakan untuk R\&D, Belinda L Heath memandang ada 4 (empat) aspek penting yang perlu untuk dipertimbangkan saat merancang sebuah kebijakan insentif perpajakan. 
Keempat aspek tersebut adalah (a) modal, (b) efektifitas, (c) efisiensi, dan (d) biaya administratif.

Menurut Heath ada dua jenis modal, yaitu modal horisontal dan modal vertikal. Modal horisontal berupa "(penerapan) beban pajak yang sama untuk mereka yang memiliki kemampuan yang sama untuk membayarnya". Hal ini sulit untuk diterapkan dalam sistem insentif perpajakan yang berbasis pendekatan inkremental. Ia mencontohkan, dua perusahaan X dan Y yang memperoleh penghasilan yang sama di tahun $\mathrm{A}$, belum tentu sama-sama memperoleh insentif perpajakan. Jika pengeluaran $R \& D$ perusahaan $X$ ditahun tersebut lebih rendah daripada pengeluaran $R \& D$ di tahun-tahun sebelumnya, maka perusahaan $\mathrm{X}$ tidak berhak memperoleh insentif perpajakan. Sebaliknya, jika pengeluran $R \& D$ perusahaan $Y$ di tahun tersebut lebih tinggi daripada pengeluaran R\&D di tahun-tahun sebelumnya, maka perusahaan $\mathrm{Y}$ berhak untuk memperoleh insentif perpajakan. Heath menolak bentuk kebijakan seperti ini. Walaupun ia mengakui ada keterbatasan dalam penerapan sistem modal horisontal, menurutnya insentif perpajakan untuk R\&D yang baik ialah insentif yang memperlakukan semua badan usaha yang memiliki pengeluaran R\&D yang sama menerima jumlah insentif perpajakan R\&D yang sama pula, sehingga mereka membayar jumlah pajak yang sama. Dalam jenis modal yang kedua, yaitu modal vertikal, heath mendefinisikannya sebagai (penerapan) beban pajak yang lebih kepada mereka yang memiliki situasi yang lebih baik." Menurutnya, insentif R\&D yang baik seharusnya memberikan porsi insentif yang lebih besar kepada perusahaan yang berpendapatan rendah, sehingga dapat mendorong usaha kecil dan menengah untuk dapat tumbuh dan berkembang. Secara khusus ia mengkritik sistem insentif R\&D Amerika Serikat yang mensyaratkan nilai pengeluaran R\&D yang sangat besar, sehingga hanya dapat dipenuhi oleh badan usaha besar dan menghambat usaha kecil dan menengah untuk memperoleh insentif $R \& D$.

Efektifitas insentif R\&D menurut Heath dapat diukur dengan semakin besarnya pengeluaran badan usaha untuk riset dan pengembangan. Menurutnya, untuk mencapai hal tersebut, sebuah moving tax base diperlukan. Caranya ialah dengan memberikan insentif $R \& D$ hanya pada badan usaha yang pengeluaran R\&D-nya lebih besar daripada pengeluaran R\&D di tahun atau tahun-tahun sebelumnya. Kebijakan ini dapat mendorong badan usaha melakukan pengeluaran R\&D yang lebih besar dari tahun ke tahun agar memenuhi persyaratan untuk menerima insentif perpajakan. Dalam konteks ini pula, Heath menekankan pentingnya kejelasan dari hal-hal yang dapat dimasukkan sebagai komponen pengeluaran R\&D. Hal ini untuk mencegah terjadinya sengketa dalam perhitungan pajak yang harus dibayar kelak. Secara tegas ia bahkan mengatakan bahwa "pembayar pajak tidaklah 
dapat dikatakan menerima insentif pajak jika untuk itu ia harus menghabiskan uang yang banyak untuk membiayai proses litigasi atau penyelesaian sengketa pajak untuk mempertahankan perhitungan pajak yang telah dilakukannya".

Insentif R\&D dapat disebut efisien jika hal tersebut mengkoreksi kegagalan pasar dan tidak mendistorsi perilaku. Heath menunjuk kebijakan yang diterapkan Jepang sebagai contoh kebijakan yang baik yang mampu mengkoreksi kegagalan pasar. Industri dalam negeri Jepang di tahun 1970-an belumlah dapat dikatakan memenuhi standar dunia, sehingga sulit untuk memenangkan persaingan dalam pasar. Oleh karena itu, kebijakan insentif R\&D saat itu ditargetkan untuk badan usaha yang melakukan riset terapan (apllied R\&D). Pada era 1980-an industri-industri Jepang telah berhasil mengejar ketertinggalan dan menjadi pemain utama dalam teknologi di dunia. Mencermati perubahan tersebut, pemerintah Jepang kemudian mengubah strategi perpajakannya dengan memberikan porsi insentif yang lebih besar untuk pengembangan riset dasar (basic/fundamental research). Sedangkan, insentif R\&D dikatakan tidak mendistorsi perilaku jika mampu mencegah badan usaha yang sesungguhnya tidak melakukan $R \& D$ dari melakukan suatu kegiatan yang seolah-olah kegiatan R\&D hanya sematamata untuk memperoleh insentif perpajakan.

Aspek terakhir yang dikemukakan oleh Heath adalah biaya administratif. Ia menyatakan bahwa kebijakan insentif $R \& D$ yang baik ialah kebijakan yang mudah untuk digunakan dan jika biaya administrasi yang terkait dengannya rendah. Suatu kebijakan dikatakan mudah digunakan jika setiap pembayar pajak dapat dengan mudah mengetahui aktifitas apa saja yang termasuk sebagai pengeluaran $R \& D$ dan berapa jumlah insentif pajak yang dapat diperoleh. Kejelasan tersebut membuat setiap pembayar pajak mudah untuk menghitung beban pajak yang harus dibayarnya dan juga menghitung manfaat pajak yang akan diperolehnya. Dengan kejelasan itu pula, administrator pajak tidak perlu menghabiskan waktu banyak untuk menganalisis hasil perhitungan dari wajib pajak. Potensi terjadinya sengketa karena perbedaan hasil perhitungan pun dapat lebih diminimalisir. Hal lain yang berkaitan dengan pengadministrasian insentif pajak ialah mengenai personil yang menangani. Sebaiknya, pemerintah tidak perlu mengangkat personil yang khusus menangani insentif $R \& D$, tetapi menggunakan personil yang telah ada dengan memberikan pelatihan khusus tambahan. Dengan demikian, biaya untuk penambahan personil baru tersebut dapat dihindarkan. 


\section{Berbagai Kelemahan dalam PP No. 35 Tahun 2007}

PP No. 35 Tahun 2007 memiliki beberapa kelemahan yang sangat fundamental. Secara singkat dapat dikatakan bahwa hal-hal yang diatur dalam PP ini banyak yang bersifat sumir atau tidak jelas. Ada tiga alasan yang dapat dikemukakan disini. Pertama, karena ruang lingkupnya terlalu luas. Kedua, karena pengaturan teknisnya tidak dijabarkan secara detil dan ditinggalkan untuk menjadi materi muatan Peraturan Menteri. Ketiga, karena finalisasi dari insentif perpajakan dan kepabenan diserahkan kepada instansi selain kementerian ristek tanpa memberikan panduan yang memadai bagaimana finalisasi tersebut akan dilakukan dan tanpa memberikan jaminan pelaksanaan rekomendasi secara efektif oleh instansi perpajakan dan kepabeanan yang dimaksud.

Untuk lebih memperjelas lagi, dalam bagian berikut akan dipaparkan kelemahan-kelemahan PP No. 35 Tahun 2007 dari 4 aspek, yaitu aspek pengaturan mengenai jenis insentif, target pemberian insentif, kriteria untuk memperoleh insentif, serta pengadministrasian insentif dan koordinasi antar instansi.

\section{A. Jenis Insentif}

Dalam PP No. 35 Tahun 2007 diatur tiga jenis insentif yang dapat diberikan pada badan usaha, yaitu insentif perpajakan, kepabeanan, dan/atau bantuan teknis penelitian dan pengembangan (Pasal 6 ayat (2)). Namun besar dan jenis insentif perpajakan dan kepabeanan tersebut diatur dalam ketentuan Peraturan Perundang-undangan di bidang perpajakan dan kepabeanan (Pasal 6 ayat (3)).

Rumusan pasal ini sangat tidak praktis dan membuka ruang tafsir yang luas. Hal tersebut dikarenakan para pihak yang berkepentingan harus mencari terlebih dahulu apa sesungguhnya jenis insentif perpajakan dan kepabeanan yang dimaksud dalam peraturan perundang-undangan di bidang perpajakan dan kepabeanan. Pekerjaan ini sangatlah kompleks, karena peraturan perundang-undangan di bidang perpajakan dan kepabeanan sangatlah banyak. Selain itu, halhal yang dianggap sebagai insentif perpajakan dan kepabeanan jenisnya sangat beragam. Dapatlah diprediksi bahwa dalam praktek nantinya akan terjadi perbedaan tafsiran misalnya antara badan usaha dengan ditjen pajak mengenai jenis insentif yang dimaksud. Persoalan lain yang bisa muncul ialah jika ternyata dalam ketentuan hukum perpajakan dan kepabeanan, besar dan jenis insentif tersebut belum diatur atau sudah diatur tetapi rumusannya masih secara umum dan 
belum ada pengaturan teknisnya, yang akan mengakibatkan pasal tersebut terancam tidak dapat dilaksanakan.

Idealnya, rumusan pasal ini telah memuat besar dan jenis insentif perpajakan dan kepabeanan secara rinci. Materi tersebut sangat sesuai untuk dimuat didalam suatu Peraturan Pemerintah (PP), karena PP adalah jenis peraturan yang sifatnya inter-departemen. Oleh karena itu, untuk isu ini sesungguhnya kementerian ristek dan departemen keuangan dapat saling bekerjasama, karena penentuan besar dan jenis insentif tersebut sangat berkaitan dengan misi dan kewenangan dari kedua lembaga tersebut. Dengan memberikan diskresi penuh untuk pengaturan lebih lanjut kepada departemen keuangan, pelaksanaan peraturan ini menjadi bergantung pada kehendak baik (good will) dari departemen keuangan atau adanya tekanan dari Presiden kepada Menteri Keuangan.

Untuk memperoleh gambaran mengenai rumusan pengaturan yang rinci, pengaturan di India dan Inggris dapat digunakan sebagai perbandingan. Besar dan jenis insentif yang diatur di India diantaranya adalah (a) pengurangan dari pajak penghasilan hingga 150\% terhadap semua pengeluaran R\&D yang dilakukan oleh badan usaha sendiri (inhouse) yang memenuhi ketentuan, (b) pengurangan pajak untuk riset yang disponsori dan didanai dengan dana publik dan terhadap proyek in-house R\&D tertentu yang disetujui, (c) pengecualian dari bea masuk untuk barang modal, aksesoris, dan bahan habis pakai yang diimpor untuk keperluan R\&D oleh unit R\&D atau lembaga yang telah disetujui oleh pemerintah, (d) pengesampingan tarif cukai untuk indigenous items yang dibeli untuk keperluan R\&D oleh lembaga tertentu yang telah disetujui oleh pemerintah, (e) allowance depresiasi yang diakselerasikan terhadap pabrik dan mesin yang berbasiskan indigenous technology (teknologi dalam negeri), (f) pengecualian bea masuk untuk impor yang berkaitan dengan proyek R\&D yang didukung oleh pemerintah, (g) tax holiday selama 10 tahun untuk badan usaha R\&D komersial, dan pengurangan hingga sebesar $125 \%$ untuk pembayaran apapun yang dibuat kepada badan usaha yang melakukan kegiatan $R \& D$, dan (i) pengesampingan tarif cukai selama 3 tahun untuk produk yang diproduksi berdasarkan teknologi yang dikembangkan di dalam negeri dan dipatenkan di sedikitnya dua dari negara-negara sebagai berikut: India, Uni Eropa (satu negara), Amerika Serikat, dan Jepang. Sedangkan di Inggris diatur bahwa badan usaha yang memenuhi syarat untuk memperoleh insentif ini berhak untuk mendapat pengurangan pajak penghasilan sampai sebesar $150 \%$ dari pengeluaran R\&D yang dilakukan. Sedangkan, bagi 
badan usaha yang mengalami kerugian, badan usaha bisa memperoleh pembayaran dari negara sampai sejumlah $24 \%$ dari total pengeluaran R\&D yang telah dilakukannya. Syarat untuk memperoleh insentif ini ialah bahwa pengeluaran R\&D tersebut sedikitnya berjumlah $£ 25,000$ dalam satu tahun dan bahwa proyek riset tersebut tidak menerima pembiayaan apapun dari pemerintah.

Dalam menentukan besar dan jenis insentif tersebut sangat diperlukan kerjasama dari para ekonom, ahli perpajakan, ahli yang menguasai peta kemampuan teknologi nasional, perencana pembangunan nasional, dan ahli hukum. Ahli yang menguasai peta kemampuan teknologi nasional dan ekonom akan memberikan gambaran mengenai pencapaian terkini Indonesia di bidang teknologi dan ekonomi dibandingkan dengan negara-negara lain di regional maupun di lingkup Internasional. Kemudian, mereka bersama-sama dengan ahli perencanaan pembangunan nasional harus merumuskan target kemajuan seperti apa yang diinginkan. Target tersebut haruslah spesifik, sehingga diharapkan dapat lebih mudah dikelola dan dievaluasi. Kemudian, ahli perpajakan akan merumuskan besar dan jenis perpajakan yang dapat diberikan untuk mewujudkan target tersebut. Ia juga harus dapat menghitung berapa besar penerimaan pajak yang akan berkurang dengan adanya insentif tersebut, berapa besar biaya administrasi yang efisien bagi pemerintah dan bagi badan usaha pemohon insentif, dan berapa besar potensi penerimaan pajak dalam jangka panjang jika kebijakan ini berhasil. Terakhir, ahli hukumlah yang akan merumuskan konsep tersebut dalam bahasa normatif sesuai dengan tata cara penyusunan ketentuan perundangundangan yang berlaku.

\section{B. Target Pemberian Insentif}

Pihak yang berhak menerima insentif dirumuskan secara umum dalam PP No. 35 Tahun 2007, yaitu Badan Usaha yang meliputi badan usaha swasta berbentuk perseoran terbatas, Badan Usaha Milik Negara, Badan Usaha Milik Daerah, dan Koperasi (Pasal 2). Ada dua persoalan yang dapat muncul dari rumusan ini. Pertama, karena tidak ada pembatasan, maka jumlah badan usaha yang berpeluang untuk mengajukan insentif sangatlah banyak. Apabila dalam prakteknya jumlah badan usaha yang mengajukan permohonan jumlahnya sedikit, maka dapat dikatakan kebijakan ini telah gagal dalam menarik minat badan usaha. Tetapi, apabila dalam prakteknya badan usaha yang benar-benar mengajukan permohonan jumlahnya sangat banyak, maka 
hal ini akan melahirkan beban dan biaya administratif yang sangat besar. Padahal, kualitas dari pemohon belum tentu seperti yang diinginkan, karena bisa saja mereka sebenarnya tidak melakukan riset tetapi membuat laporan seolah-olah mereka melakukan riset hanya sekedar untuk mendapat insentif (terjadi distorsi pada perilaku). Jika kondisi ini yang terjadi, maka negara sudah pasti mengeluarkan biaya (tax expenditure) tetapi peningkatan kemampuan R\&D badan usaha belum tentu terjadi.

Persoalan kedua, tidak ada sektor usaha tertentu yang secara khusus merasa dirangsang untuk tumbuh. Padahal, pemerintah seharusnya melakukan seleksi untuk memilih jenis badan usaha yang diinginkan untuk tumbuh dan mendapat benefit dari insentif ini. Seleksi tersebut diperlukan, karena pemberian insentif R\&D sesungguhnya ditujukan untuk meningkatkan investasi R\&D dari perusahaan yang sudah ada atau untuk menarik perusahaan yang berbasis R\&D untuk berinvestasi di Indonesia. Tahapan awal untuk memilih jenis badan usaha yang sesuai adalah dengan melihat daftar badan usaha yang tingkat kepatuhan membayar pajaknya tinggi dan daya saing produknya di tingkat regional dan internasional masih dapat ditingkatkan lagi hingga ke level penguasa pasar. Badan usaha semacam itulah yang layak untuk diberikan insentif, karena efektifitas kebijakan insentif perpajakan sesungguhnya bergantung pada kepatuhan dari wajib pajak dalam membayar pajak.

Idealnya, pihak yang ditargetkan sebagai penerima insentif dirumuskan secara jelas. Dalam hal ini pengalaman Jepang dapat dijadikan sebagai perbandingan. Pada tahun 1970-an Jepang mengeluarkan kebijakan insentif untuk mendorong kemajuan industri riset terapan. Oleh karena itu, penerima insentifnya adalah badan usaha yang dapat menunjukkan bukti telah melakukan riset terapan. Setelah industri yang berbasis riset terapan cukup mapan dalam penguasaan pasar, kebijakan insentif dirubah sehingga penerimanya menjadi industri yang berbasis riset fundamental. Di singapura, pemerintahnya mengeluarkan dua jenis insentif. Jenis insentif yang pertama ditujukan secara umum, yaitu untuk semua badan usaha, baik yang besar maupun yang kecil. Jenis insentif yang kedua ditujukan secara khusus untuk sektor usaha kecil dan menengah. Di belgia, target penerima insentif $R \& D$ diantaranya adalah badan usaha yang disebut sebagai "perusahaan muda yang inovatif" (young innovative companies), yaitu badan usaha yang berskala kecil (mempekerjakan kurang dari 50 orang atau pengeluaran tahunannya tidak lebih dari 
7,300,000 EUR) dan badan usaha yang membayar gaji untuk karyawan peneliti (scientific staff).

\section{Kriteria Untuk Memperoleh Insentif}

Untuk memperoleh insentif R\&D, PP No. 35 Tahun 2007 mewajibkan setiap badan usaha mengajukan permohonan kepada Menristek untuk mendapatkan rekomendasi insentif dengan menyertakan proposal kegiatan dan bentuk insentif yang diminta (Pasal 8). Jika rekomendasi diberikan, badan usaha tersebut mengajukan permohonan lagi ke lembaga yang berwenang dalam bidang perpajakan dan kepabeanan. PP No. 35 Tahun 2007 tidak mengatur mengenai bukti-bukti apa yang harus dipenuhi suatu badan usaha untuk memperoleh insentif (incentive eligilibilty). Bagaimana format dari proposal yang merupakan bagian dari permohonan pun tidak dijelaskan. Oleh karena itu, para pemohon dapat berkreasi dalam proposalnya, namun haruslah memuat informasi yang akan dievaluasi oleh Tim Pengkajian dan Penilaian yang meliputi informasi tentang (a) kegiatan peningkatan kemampuan perekayasaan, inovasi, dan difusi teknologi, (b) potensi peningkatan kinerja produksi dan/atau daya saing barang dan/atau jasa; dan (c) pemanfaatan hasil penelitian dan pengembangan di dalam negeri, dan (d) penggunaan sumber daya dalam negeri. (Pasal 9).

Rumusan tersebut memiliki tiga kelemahan. Pertama, tidak ada kejelasan mengenai kaitan pemberian insentif dengan peningkatkan kuantitas pengeluaran R\&D dan peningkatan kualitas kemampuan R\&D. Dari segi kuantitas, besarnya jumlah pengeluaran R\&D adalah indikator kinerja $R \& D$ di suatu badan usaha. Kebijakan insentif $R \& D$ seharusnya mendorong badan usaha untuk memperbesar pengeluaran R\&D nya dari tahun ke tahun, sehingga peningkatan kinerja $R \& D$ dapat terukur. Selain itu, jumlah minimal pengeluaran $R \& D$ sesungguhnya perlu diatur, sehingga pemerintah dapat memastikan bahwa badan usaha yang akan menerima insentif adalah badan usaha yang serius dalam melakukan kegiatan R\&D.

Kedua, proposal dapat diartikan sebagai rencana $R \& D$, padahal sesungguhnya yang diperlukan oleh pemerintah adalah bukti-bukti pengeluaran yang terkait R\&D. Berdasarkan bukti-bukti pengeluaran tersebutlah pemerintah dapat menilai keseriusan upaya peningkatan R\&D yang dilakukan oleh badan usaha yang bersangkutan, mengetahui bidang teknologi yang menjadi fokus dan kekuatannya, dan prospek implementasi hasil $R \& D$ tersebut di pasar. Rencana $R \& D$ 
tidak dapat digunakan sebagai dasar untuk pemberian insentif, karena bisa disalahgunakan, yaitu badan usaha yang tidak melaksanakan rencana $R \& D$-nya tetapi tetap memperoleh insentif perpajakan.

Ketiga, badan usaha kemungkinan tidak akan mempersiapkan proposal dengan baik, karena ketidakjelasan materi yang perlu disiapkan. Untuk dapat mengevaluasi keseriusan suatu badan usaha dalam melakukan R\&D, tim evaluator sangat memerlukan bukti pengeluaran R\&D yang telah ditelakukan. Tidak jelasnya pengeluaran seperti apa yang dapat diperhitungkan sebagai biaya R\&D, diprediksi akan membuat badan usaha tidak mengalokasikan sumber dayanya untuk mendokumentasikan secara khusus biaya-biayanya untuk kepentingan itu.

Idealnya, pemerintah harus membuat kebijakan insentif R\&D yang khusus diperuntukkan bagi badan usaha yang memang serius dalam melakukan kegiatan R\&D. Selain itu, mengingat secara alamiah badan usaha adalah entitas yang senantiasa beroperasi secara efisiensi, kejelasan kriteria menjadi sangat penting. Dengan kejelasan tersebut mereka dapat menghitung secara cermat sumber daya yang akan dikeluarkannya. Jika berdasarkan hitungan mereka hal tersebut membuat perusahaan lebih efisien, maka mereka pasti akan mengalokasikan sumber dayanya untuk itu. Dalam konteks inilah, pemerintah perlu menyadari bahwa bagi badan usaha ketidakjelasan berarti biaya yang tidak terukur. Hal tersebut sangat tidak disukai badan usaha, karena ketidakterukuran tersebut membuat mereka tidak dapat membuat perencanaan usahanya dengan baik.

Di beberapa negara seperti Amerika Serikat, Perancis, dan Australia, kriteria yang ditetapkan agar suatu badan usaha berhak memperoleh insentif ialah adanya bukti bahwa pengeluaran R\&D di tahun ia mengajukan insentif adalah lebih besar daripada pengeluaran R\&D di tahun atau tahun-tahun sebelumnya (pendekatan inkrementalis). Di New Zealand badan usaha yang ingin memperoleh insentif adalah yang telah mengeluarkan uang lebih dari $\$ 20,000$ untuk kegiatan R\&D.

Di Kanada bahkan terdapat pengertian mengenai kegiatan R\&D untuk memastikan bahwa penerima insentif adalah badan usaha yang kegiatan R\&D-nya sesuai dengan rencana pembangunan teknologi di negara tersebut. Pengertian tersebut adalah: (a) R\&D tersebut menunjukkan adanya kemajuan saintifik atau teknologi (scientific or technological advancement). Riset tersebut harus melibatkan kegiatan eksperimen atau analisis yang melebihi standar dalam praktek dan riset tersebut harus mampu mendobrak hambatan-hambatan (push the 
barriers), (b) R\&D tersebut fokus pada ketidakpastian saintifik dan teknologis yang mana tidak ada kejelasan bagaimana tujuan-tujuan riset tersebut dapat dicapai, (c) R\&D harus memiliki konten saintifik dan teknis yang dibuktikan melalui suatu investigasi yang sistematik dan terdokumentasi dengan baik, yang dilakukan oleh personal berkualifikasi tertentu dengan pengalaman yang relevan.

Contoh dari kegiatan yang dapat memenuhi persyaratan agar badan usaha dapat memperoleh insentif R\&D di Kanada adalah: (a) pengembangan produk baru, (b) pengembangan suatu material baru atau perbaikan kualitas dari material yang ada, (c) pembuatan perbaikan-perbaikan dalam proses, (d) pengembangan software, (e) uji klinis dari suatu obat atau alat medik baru. Sebaliknya kegiatan riset yang pengeluarannya tidak dapat dihitung untuk pengurangan pajak adalah: (a) riset pasar atau promosi penjualan, (b) pengawasan kualitas barang (quality control) atau pengetesan rutin terhadap material, perangkat, produk atau proses, (c) riset dalam lingkup ilmu sosial atau humaniora, (d) prospekting, eksplorasi, atau pengeboran, atau produksi bahan tambang, minyak, dan gas alam, (e) produksi komersial dari satu material yang baru atau yang sudah ditingkatkan kualitasnya, perangkat, atau produk, atau penggunaan komersial dari satu proses yang baru atau yang sudah ditingkatkan kualitasnya, (f) perubahan gaya (style changes), (g) pengumpulan data secara rutin. Jenis pengeluaran R\&D yang boleh dihitung adalah upah dan gaji, barang modal, bahan baku, pengeluaran operasional (overhead), dan semua riset yang dikontrakkan ke pihak ketiga. Pengeluaran R\&D yang tidak dapat memperoleh insentif adalah pengeluaran untuk perolehan tanah atau gedung, pembelian peralatan bekas, pengeluaran yang terkait dengan sewa tertentu, pengeluaran yang dibuat untuk perolehan suatu hak yang terkait dengan pengembangan riset dan eksperimen.

\section{Pengadministrasian Insentif dan Koordinasi Antar Instansi}

Berdasarkan PP No. 35 Tahun 2007 instansi pemerintah yang berkaitan dengan pengelolaan insentif adalah Menteri yang menyelenggarakan urusan pemerintahan di bidang penelitian, pengembangan, dan penerapan ilmu pengetahuan dan teknologi yang kemungkinan besar adalah Menristek, instansi pemerintah yang menyelenggarakan bidang perpajakan dan kepabeanan yang dapat meliputi Menteri Keuangan, Direktorat Jenderal Pajak, dan Direktorat Jenderal Bea dan Cukai, serta Tim Pengkajian dan Penilaian yang dibentuk oleh Menristek (Pasal 9 dan Pasal 11). Menristek berwenang 
untuk membentuk Tim Pengkajian dan Penilaian, memberikan atau menolak memberikan rekomendasi, dan menerima penyerahan laporan kegiatan peningkatan kemampuan, perekayasaan, inovasi, dan difusi teknologi. Menteri Keuangan, Dirjen Pajak, atau Dirjen Bea Cukai berwenang untuk memproses pengajuan permohonan insentif perpajakan oleh badan usaha yang telah memperoleh rekomendasi insentif dari Menristek. Tim Pengkajian dan Penilaian berwenang untuk mengkaji dan menilai permohonan yang berisi proposal yang diajukan oleh badan usaha dan memberikan saran dan pertimbangan kepada Menristek.

Ada 2 (dua) persoalan yang berkaitan dengan ketentuan-ketentuan tersebut. Pertama, tidak ada jaminan bahwa instansi pemerintah yang berwenang di bidang perpajakan dan kepabeanan akan menindaklanjuti rekomendasi insentif dari Menristek. Dalam PP No. 35 Tahun 2007 jangka waktu untuk memproses permohonan telah ditentukan secara spesifik. Tetapi hal tersebut tidak diatur untuk instansi pemerintah di bidang perpajakan dan kepabeanan. Selain itu instansi pemerintah di bidang perpajakan dan kepabeanan memerlukan peraturan pelaksana sebagai landasan hukum untuk kegiatan mereka. Peraturan pelaksana tersebut belum ada dan Menristek tidak dapat memaksa pembuatannya.

Kedua, negara secara kongkrit akan mengeluarkan biaya untuk operasional dan pelatihan personil, sementara rencana benefit untuk negara dari kebijakan insentif ini masih belum meyakinkan. Beberapa pengeluaran terkait personil yang dapat diprediksi akan diperlukan dalam pelaksanaan kebijakan ini adalah (a) upah, gaji, atau insentif dari anggota Tim Pengkajian dan Penilaian, (b) upah, gaji, atau insentif dari aparat di instansi pemerintah di bidang perpajakan dan kepabeanan, (c) biaya pelatihan untuk anggota Tim Pengkajian dan Penilaian, (d) biaya pelatihan untuk aparat di perpajakan dan kepabeanan. Agar pengeluaran tersebut menjadi biaya yang produktif, rencana penerimaan negara dari kebijakan insentif ini haruslah disusun secara kongkrit pula.

\section{E. Solusi Mengatasi Kelemahan PP No. 35 Tahun 2007 Melalui Pembentukan Peraturan Menteri}

Untuk melaksanakan PP No. 35 Tahun 2007, pemerintah yang dalam hal ini direpresentasikan oleh Menteri Negara Riset dan Teknologi (Menristek) perlu mengeluarkan Peraturan Menteri, yaitu mengenai bantuan teknis penelitian dan pengembangan (diamanatkan 
oleh Pasal 7), tata cara pengajuan permohonan rekomendasi insentif (diamanatkan oleh Pasal 8), dan susunan keanggotaan dan tata kerja tim pengkajian dan penelitian (diamantkan oleh Pasal 9). Sedangkan Menteri Keuangan perlu mengeluarkan Peraturan Menteri yang mengatur mengenai besar dan jenis insentif perpajakan terkait $R \& D$, serta tata cara pemberian insentif perpajakan tersebut. Untuk efisiensi dan efektifitas Menteri Keuangan dan Menristek dapat bekerjasama dan membuat Peraturan Menteri Bersama yang mengatur tentang besar dan jenis insentif perpajakan, serta tata cara pengajuan rekomendasi dan pemberian insentif perpajakan. Pengaturan untuk susunan keanggotaan dan tata kerja tim pengkajian dan penelitian, serta pengaturan mengenai bantuan teknis penelitian dan pengembangan, masing-masing dapat dibuat oleh Menristek dalam Peraturan Menteri tersendiri. Berikutnya akan dipaparkan materi muatan yang dapat diatur dalam Peraturan Menteri Bersama tersebut.

\section{Prinsip}

Seluruh ketentuan yang terdapat dalam peraturan ini harus dibuat dengan menyadari atau mempertimbangkan hal-hal sebagai berikut:

a. Bahwa insentif perpajakan untuk meningkatkan kemampuan R\&D haruslah diberikan hanya pada badan usaha yang serius telah melakukan pengeluaran R\&D dan bukan pada badan usaha yang baru berencana melakukan kegiatan R\&D;

b. Bahwa tujuan pemberian insentif adalah untuk mendorong badan usaha yang sudah ada meningkatkan pengeluarannya untuk $R \& D$ dan untuk menarik badan usaha yang kuat basis R\&Dnya untuk berinvestasi di Indonesia;

c. Bahwa prosedur pengadministrasian insentif perpajakan R\&D haruslah sederhana, jelas, dan cepat untuk menghindari terjadinya kolusi, korupsi, dan pengeluaran negara yang tidak efisien;

d. Bahwa pemberian insentif perpajakan hanya akan efektif bagi badan usaha yang patuh dalam membayar pajak, sehingga implementasi insentif harus dilakukan secara paralel dengan meningkatkan kuantitas dan kualitas kepatuhan badan usaha dalam membayar pajak; 
e. Bahwa jenis kegiatan R\&D yang layak untuk memperoleh insentif adalah yang sesuai dengan Visi Pembangunan Iptek 2025, sehingga kebijakan ini dapat menunjang kebijakan yang terdahulu.

Hal-hal tersebut diatas tidak perlu dimasukkan dalam pasalpasal di peraturan, tetapi perlu dimuat di bagian penjelasan umum. Dengan demikian, lembaga pelaksana dan masyarakat dapat mengetahui dasar pemikiran dari ketentuan yang ada dalam peraturan tersebut.

\section{Jenis Insentif}

Pilihan jenis insentif perpajakan yang tersedia sesungguhnya cukup banyak. Namun untuk menentukan jenis dan besaran insentif yang tepat, perlu perhitungan dan pertimbangan yang matang dari ahli yang memahami persoalan ekonomi dan perpajakan. Selain itu perlu pula dipertimbangkan potensi penyelewengan yang dapat terjadi sebelum memilih suatu jenis insentif, sehingga langkah-langkah antisipasinya dapat di persiapkan dengan baik. Adapun pilihan insentif yang tersedia diantaranya adalah:

a. pengurangan dari pajak penghasilan terhadap semua pengeluaran R\&D yang dilakukan oleh badan usaha sendiri (in-house), baik yang pendanaannya bersumber dari anggaran badan usaha itu sendiri maupun dari luar badan usaha tersebut dalam dan luar negeri. jika pemerintah ingin menarik minat yang besar dari badan usaha, besaran pengeluaran R\&D yang bisa dikurangi dapat dinaikkan lebih besar dari klaim yang diajukan (lihat contoh Singapura);

b. pengurangan dari pajak penghasilan terhadap semua pengeluaran $R \& D$ yang dilakukan oleh badan usaha yang risetnya dilakukan oleh lembaga lain (badan usaha hanya bertindak sebagai pemberi dana);

c. pengurangan pajak untuk riset yang disponsori dan didanai dengan dana apbn/apbd;

d. pengecualian dari bea masuk untuk barang modal, aksesoris, dan bahan habis pakai yang diimpor untuk keperluan R\&D;

e. pemberlakuan aturan depresiasi khusus untuk pabrik dan mesin yang berbasiskan teknologi dalam negeri; 
f. tax holiday untuk badan usaha R\&D komersial yang akan menanamkan investasinya di Indonesia. perlu diatur mengenai nilai minimum dari investasi yang berhak memperoleh insentif ini, jangka waktu yang jelas mengenai pemberian insentif, mewajibkan reinvestasi keuntungan digunakan di dalam negeri dalam jangka waktu tertentu, dan mengatur ancaman sanksi yang berat jika badan usaha berhenti beroperasi kurang dari jangka waktu keberlakuan insentif;

g. pengesampingan tarif cukai selama jangka waktu tertentu untuk produk yang diproduksi berdasarkan teknologi yang dikembangkan di dalam negeri dan dipatenkan di beberapa negara tertentu tempat produk tersebut dipasarkan.

\section{Penerima Insentif}

Ditinjau dari waktu pendiriannya, badan usaha dapat dibedakan menjadi perusahaan yang sudah berdiri (existing enterprise) dan perusahaan yang akan didirikan (future enterprise). Pemerintah sebaiknya mentargetkan pendirian future enterprise yang basis teknologi, permodalan, dan pemasaran produknya kuat secara global. Perusahaan semacam itu biasanya memiliki tingkat kepatuhan perpajakan yang cukup baik, karena ketidakpatuhan dapat meningkatkan resiko investasi mereka. Sedangkan untuk perusahaan yang sudah ada, ditinjau dari kekuatan permodalannya dapat dibedakan menjadi perusahaan kecil, menengah, dan besar. Pemerintah sebaiknya melakukan pengaturan dengan mengkombinasikan dua pendekatan, yaitu pengaturan yang bersifat umum yang berlaku untuk semua badan usaha dan pengaturan yang bersifat khusus yang berlaku untuk badan usaha kecil dan menengah. Untuk menyeleksi badan usaha yang serius melakukan R\&D, dapat ditetapkan persyaratan berupa jumlah pengeluaran R\&D minimal atau jenis kegiatan R\&D yang dapat diklaim sebagai pengeluaran.

\section{Kriteria untuk Menerima Insentif}

Pada prinsipnya tidak semua badan usaha dapat memperoleh insentif R\&D. Agar jelas bagi semua pihak yang berkepentingan, peraturan ini harus mengatur apa saja persyaratan yang harus 
dipenuhi agar suatu badan usaha dapat memperoleh insentif. Berdasarkan pada pengalaman di negara-negara lain, pengaturan tersebut dapat berupa:

\section{a. Pembatasan ruang lingkup dari proyek $R \& D$}

Jika mengacu pada Visi Iptek 2025, pemerintah dapat mengatur bahwa proyek $R \& D$ disini adalah proyek $R \& D$ yang berkaitan dengan kemandirian dan ketahanan pangan, perbaikan kualitas pelayanan kesehatan dan pendidikan, pengelolaan lingkungan termasuk pengelolaan sumberdaya genetik, sumberdaya lahan dan air, pemanfaatan sumberdaya kelautan, kebumian dan kedirgantaraan secara terkendali, transportasi dan logistik, energi, manufaktur, teknologi informasi dan bahan baru.

\section{b. Perincian jenis kegiatan R\&D yang pengeluarannya dapat diklaim}

Dalam hal ini pemerintah bisa mengatur bahwa kegiatan R\&D yang dimaksud adalah (a) pengembangan produk baru, (b) pengembangan suatu material baru atau perbaikan kualitas dari material yang ada, (c) pengembangan proses, (d) pengembangan software, (e) uji klinis dari suatu obat atau alat medik baru. Sebaliknya kegiatan riset yang pengeluarannya tidak dapat dihitung untuk pengurangan pajak adalah: (a) riset pasar atau promosi penjualan, (b) pengawasan kualitas barang (quality control) atau pengetesan rutin terhadap material, perangkat, produk atau proses, (c) prospekting, eksplorasi, atau pengeboran, atau produksi bahan tambang, minyak, dan gas alam, (d) perubahan gaya, tampilan artistik, dan desain industri, dan (e) pengumpulan data secara rutin.

\section{c. Perincian jenis pengeluaran yang merupakan komponen pengurangan}

Tujuan pengaturan ini adalah untuk mempermudah badan usaha dalam mempersiapkan proposal atau permohonan insentif dan bagi instansi pemerintah yang terkait untuk mempermudah dalam mengevaluasi permohonan insentif. Pemerintah dapat menetapkan bahwa jenis pengeluaran R\&D yang boleh dihitung adalah upah dan gaji tenaga peneliti, barang modal untuk keperluan kegiatan atau proyek R\&D, 
bahan baku, pengeluaran operasional (overhead), dan semua biaya riset yang dikeluarkan oleh badan usaha tetapi pelaksanaannya oleh pihak di luar badan usaha. Namun untuk menghindari klaim pengeluaran yang besar tetapi tidak memiliki dampak yang cukup signifikan dalam peningkatan kemampuan $\mathrm{R} \& \mathrm{D}$, pemerintah dapat melarang beberapa pengeluaran tertentu untuk dihitung sebagai komponen pengurangan pajak. Misalnya, pengeluaran untuk perolehan tanah atau gedung, pembelian peralatan bekas, pengeluaran yang terkait dengan sewa tertentu, pengeluaran yang dibuat untuk perolehan suatu hak yang terkait dengan pengembangan riset dan eksperimen.

\section{d. Penentuan jumlah pengeluaran R\&D}

Keseriusan badan usaha dalam melakukan kegiatan R\&D dapat tercermin dari besarnya pengeluaran $R \& D$ per tahun. Dalam konteks ini pemerintah memiliki dua pilihan pengaturan, yaitu mengatur persyaratan jumlah pengeluaran R\&D secara inkremental atau berdasarkan jumlah minimum. Dalam pendekatan inkrementalis, badan usaha yang berhak memperoleh insentif adalah yang pengeluaran $R \& D$ ditahun permohonan insentifnya diajukan lebih besar dari pengeluaran R\&D di tahun atau tahun-tahun sebelumnya. Pemerintah bahkan bisa menetapkan persentase kenaikan tertentu dalam metode inkrementalis tersebut. Dalam pendekatan pengeluaran minimal, pemerintah dapat menetapkan bahwa insentif akan diberikan jika pengeluaran R\&D suatu badan usaha melebihi jumlah minimal tertentu. Kedua pendekatan tersebut dapat digunakan bersama-sama atau dikombinasikan.

\section{Tata Cara Pengajuan Permohonan Rekomendasi Insentif}

Bagian ini dapat berisi hal-hal sebagai berikut:

a. Rincian informasi yang harus dimuat dalam proposal permohonan insentif;

b. Kewajiban badan usaha untuk memberikan bukti-bukti adanya proyek atau kegiatan $R \& D$ yang sesuai dengan kriteria; 
c. Kewajiban badan usaha untuk memberikan bukti-bukti mengenai jenis badan usaha tersebut (besar, menengah, atau kecil);

d. Biaya-biaya yang berkaitan dengan pengurusan permohonan insentif.

\section{Tata Cara Pemberian Insentif Oleh Instansi Perpajakan dan Kepabeanan}

Bagian ini dapat berisi hal-hal sebagai berikut:

a. Kewajiban menindaklanjuti rekomendasi insentif yang telah dikeluarkan Menristek;

b. Kewajiban badan usaha untuk memberikan bukti-bukti pengeluaran R\&D yang telah dilakukan (jika menggunakan pendekatan inkrementalis, bukti pengeluaran R\&D di tahun atau tahun-tahun sebelumnya juga perlu dilampirkan);

c. Jangka waktu pemrosesan permohonan;

d. Prosedur dalam hal terjadi perbedaan perhitungan antara badan usaha selaku wajib pajak dan fiskus;

e. Biaya-biaya yang berkaitan dengan pengurusan permohonan insentif.

\section{Penutup}

\section{A. Kesimpulan}

Berdasarkan pada hasil yang diperoleh dalam penelitian ini dapat disimpulkan hal-hal sebagai berikut.

Pertama, Bahwa kedudukan PP No. 35 Tahun 2007 bergantung pada pengaturan di bidang perpajakan dan kepabeanan. Hal-hal yang terdapat dalam PP tersebut memerlukan penjelasan yang lebih rinci dari pengaturan di bidang perpajakan dan kepabeanan. Apabila instansi pemerintah yang berwenang dalam bidang perpajakan dan kepabeanan tidak melakukan upaya untuk merinci atau membuat pengaturan yang teknis untuk memproses pengajuan permohonan insentif R\&D, maka PP No. 35 Tahun 2007 dapat tidak efektif.

Kedua, persamaan antara pengaturan insentif $R \& D$ di Indonesia dan di luar negeri ada pada tujuannya, yaitu untuk meningkatkan kemampuan R\&D badan usaha di dalam negeri melalui insentif untuk mendorong adanya peningkatan dalam pengeluaran $R \& D$ dan menarik 
investor-investor baru ke dalam negeri. Perbedaan banyak terjadi dalam aspek teknis, yaitu bahwa pengaturan Indonesia masih bersifat terlalu umum dan terlalu menggantungkan pada pembentukan peraturan-peraturan pelaksana seperti peraturan menteri. Sedangkan, pada beberapa negara di luar negeri, pengaturan insentif sudah lebih detail, sehingga lebih mudah diadministrasikan.

Ketiga, elemahan dalam PP No. 35 Tahun 2007 secara singkat adalah perumusannya yang sumir dan terlalu bergantung pada peraturan menteri. Secara lebih rinci kelemahan tersebut dapat ditinjau dari 4 aspek yaitu aspek pengaturan mengenai jenis insentif, target pemberian insentif, kriteria untuk memperoleh insentif, serta pengadministrasian insentif dan koordinasi antar instansi.

\section{B. Saran}

Untuk membuat PP No. 35 Tahun 2007 dapat dilaksanakan secara efektif dan sesuai dengan tujuan pembentukannya, maka hal-hal yang dapat dilakukan adalah:

Pertama, merancang peraturan menteri bersama antara Menristek dan Menteri Keuangan;

Kedua, sebelum merancang peraturan menteri bersama tersebut perlu dilakukan riset untuk:

a. memetakan tingkat pengeluaran $R \& D$ perusahaanperusahaan di Indonesia;

b. memetakan produk hasil produksi dalam negeri yang masih berpeluang bersaing di pasar internasional;

c. memetakan pencapaian badan usaha di Indonesia dalam bidang teknologi dan ekonomi di tingkat global;

d. mengelaborasi Visi Iptek 2025 dan merumuskan cara penggunaan insentif perpajakan untuk mewujudkan visi tersebut;

e. merumuskan besar dan jenis perpajakan yang dapat diberikan untuk mewujudkan target tersebut, dengan sebelumnya menghitung berapa besar penerimaan pajak yang akan berkurang dengan adanya insentif tersebut, berapa besar biaya administrasi yang efisien bagi pemerintah dan bagi badan usaha pemohon insentif, dan berapa besar potensi penerimaan pajak dalam jangka panjang jika kebijakan ini berhasil. 
f. merumuskan konsep tersebut dalam bahasa normatif sesuai dengan tata cara penyusunan ketentuan perundang-undangan yang berlaku. 


\section{Daftar Pustaka}

Asit Advisory Studies No. 16, Tax Incentives and Foreign Direct Investment: A Global Survey, United Nations Conference on Trade and Development, 2000.

Atkinson, Robert D. Expanding the R\&D Tax Credit to Drive Innovation, Competitiveness, and Prosperity, April 2007.

Australia Department of Industry Tourism and Resources, How $R \& D$ Assistance Influence Company Behaviours, July 2007.

Bloom, Nicholas, Rachel Griffith, Alexander Klemm. Issues in the Design and Implementation of an R\&D Tax Credit for UK Firms, The Institute for Fiscal Studies, Januari 2001.

Canadian Embassy Berlin. Science and Technology Section, Research in Canada: A Summary of R\&D Tax Incentives in Canada, Januari 2007.

Cowie, Roger. Using Tax Incentives to Improve American Competitiveness: A Framework for Normative Analysis, American Business Law Journal, November, 1993.

Dumagan, Jesus C. Re-examining the Cost Effectiveness of the Research and Experimentation Tax Credit, Juni 1995.

Easson, Alex, Eric M Zolt. Tax Incentives, World Bank, Tanpa Tahun.

Eurochamber, Position Paper 2006: Position on R\&D Tax Incentives, Juli 2006.

Fletcher, Kevin. Tax Incentives in Cambodia, Lao PDR, and Vietnam, IMF Conference, Hanoi Vietnam, 16-17 Agustus 2002.

Gittel, Ross, Edinaldo Tebaldi, The Economic Impact of a Proposed R\&D Tax Credit in New Hampsire, 30 April 2007.

Hall, Bronwyn H. Effectiveness of The California R\&D Tax Credit, 15 Juni 1999.

Hall, Bronwyn H, Marta Wosinska. The California R\&D Tax Credit: Description, History, and Economic Analysis, Juni 1999.

Hasanaliyev, Orkhan. $R \& D$ Tax Policy and Firm Dynamics, tanpa tahun.

Heath, Belinda L. The Importance of Research and Development Tax Incentives in the World Market, Michigan State University-DCL "Journal of International Law", Fall 2002. 
Inland Revenue Department and New Zealand Treasury, R\&D Tax Credit: Definition, Eligibility Criteria, Eligible Expenditure, November 2006.

JaruzeIski, Barry, Kevin Dehoff, Rakesh Bordia. The Booz Allen Hamilton Global Innovation 1000: Money Isn't Everything, Strategy+Business issue 41, Winter 2005.

Mani, Sunil. Financing of Industrial Innovations in India, How Effective Are Tax Incentives for R\&D?, tanpa tahun.

Mcalpine, Debbie. Tax Credits for R\&D Investment, PricewaterhouseCooper London, 2005.

Moris, Fransisco. The US Research and Experimentation Tax Credit in the 1990s, National Science Foundation 05-316, Juli 2005.

Mulkay, Benoit, Jacques Mairesse. The Effect of the R\&D Tax Credit in France, 14 Februari 2003.

Ngowi, Honest W. Tax Incentives for Foreign Direct Investment: Types and Who Should/Should Not Qualify in Tanzania, The Tanzanet Journal.

Pouris, Anastassios. Towards a South African R\&D Tax Incentives Scheme: Fiscal Policies and Social Benefits, South African Journal of Science 99, Mei/Juni 2003.

Spire Research and Consulting, White Paper: Comparative Analysis of $R \& D$ Developments in Malaysia, November 2002.

Stads, Gert Jan, Haryono, Siti Nurjayanti. Agricultural $R \& D$ in Indonesia: Policy, Investment, and Institutional Profile, November 2007.

Stanley, Owen. The Potential Use of Tax Incentives for Indegenous Business on Indigenous Land, CAEPR Working Paper No. 17/2002.

Surrey, Stanley S. Tax Incentives as A Device for Implementing Government Policy: A Comparison With Direct Government Expenditures, Harvard Law Review, February, 1970.

Tassey, Gregory. Tax Incentives for Innovation: Time to Restructure the R\&D Tax Credit, 1 Agustus 2007.

Venghaus, Jennifer L. Tax Incentives: A Means of Encouraging Research and Development for Homeland Security?, University of Richmond Law Review, May, 2003.

Warda, Jacek. Measuring the Attractiveness of R\&D Tax Incentives: Canada and Major Industrial Countries, Desember 1999. 
Wensley, Karen, Allen Szeto. Using R\&D Tax Incentivesto Leverage Canada Foundation for Innovation Contribution, 1 Juni 1998. 